Vol. 14 (4) 169 - 173

\title{
Effect of Traditional Processing Techniques on the Nutritional and Phytochemical Composition of African Bread-Fruit (Treculia africana) Seeds
}

\section{*IFEOMA I IJEH; CHUKWUNONSO ECC EJIKE; OBINNA M NKWONTA; BRYAN C NJOKU}

Department of Biochemistry, College of Natural and Applied Sciences, Michael Okpara University of Agriculture, Umudike, PMB 7267

Umиahia, Abia State-Nigeria

\begin{abstract}
The effects of three traditional processing methods on the phytochemical, nutrient and mineral composition of Treculia africana seeds were evaluated. Mean proximate contents of dehulled raw samples $(\mathrm{g} / 100 \mathrm{mg})$ were protein $(18.32 \pm 0.54)$, fat $(1.31 \pm 0.02)$, ash $(1.62 \pm 0.02)$, crude fibre $(1.31 \pm 0.01)$ and carbohydrate $(77.44 \pm 8.46)$. Their phytochemical constituents yielded $(\mathrm{g} / 100 \mathrm{~g})$ alkaloids $(0.58 \pm 0.08)$, phenols $(0.82 \pm 0.00)$, tannins $(0.14 \pm 0.00)$, flavonoids $(1.30 \pm 0.10)$, oxalate $(11.37 \pm 0.10)$, and saponins $(0.37 \pm$ $0.03)$. Mean mineral contents $(\mathrm{mg} / 100 \mathrm{~g})$ of these raw samples were calcium $(5.34 \pm 1.15)$, magnesium $(2.00 \pm 0.35)$, iron $(8.00 \pm 0.00)$, selenium $(0.18 \pm 2.89)$, copper $(0.35 \pm 0.00)$, iodine $(0.30 \pm 0.01)$ and chromium $(0.04 \pm 0.00)$; while the vitamin A level was $2.24 \pm$ $0.22 \mu \mathrm{g} / 100 \mathrm{~g}$. Boiling and drying resulted in a significant increase in only the carbohydrate content. Dehulling and roasting resulted in a significant decrease in selenium content and all the nutrients and phytochemicals estimated except for carbohydrates and flavonoids. Roasting of undehulled samples resulted in a significant decrease only in protein, fat and carbohydrate contents, and all phytochemicals except phenolic contents; while it increased the mineral content except for selenium, significantly $(\mathrm{p}<0.05)$. All forms of processing reduced the vitamin A content of the seeds significantly $(\mathrm{p}<0.05)$. Comparing the processing methods, boiling and drying resulted in less percentage decrease in nutrient and vitamin A composition but higher percentage loss in most phytochemicals. Roasting of undehulled seeds preserved the mineral elements better than the other methods. @JASEM
\end{abstract}

The Food and Agriculture Organization (FAO) of the World Health Organization (WHO) estimated that between 1990 and 1992, 204 million sub-Saharan Africans (41\% of the population of the region) were chronically undernourished. The WHO 1995 estimates for iodine, vitamin $\mathrm{A}$ and iron deficiencies in Africa show that 181 million Africans were at risk of iodine deficiency, 1 million had xerophthalmia, while 206 million had iron deficiency or anaemia (Latham, 1997). Despite these awful pictures, the population of sub-Saharan Africa is increasing at a very high rate such that food production is not just insufficient to feed the teeming population, but the continued reliance on the regular sources of protein, energy and other nutrients presents a bleak future. It is on this premise that adequate food supply has become a burning issue in the region (FAO, 1985) and research efforts have been geared towards finding (1) alternate sources of protein, energy and other nutrients especially from readily available but hitherto underutilized plants (Giami and Wachukwu, 1997; Enujiugha and Ayodele-Oni, 2003) and (2) better processing methods that ensure longer shelf life of fairly available plant foods. The African breadfruit is one of such plants.

The African bread-fruit (Treculia africana) is an edible woody plant grown around homesteads and outlying fields. It is widely known for its large fruit heads which yield edible seeds. When extracted, these seeds are said to be nutritious if adequately processed (Ejiofor et al, 1998). This is because the seeds contain some anti-nutrients which interfere with the process of digestion (Ekpenyong 1985). The ultimate goal of processing, however, is to preserve the nutrients in order to make them available to the consumers and to remove or reduce the levels of phytochemicals which interfere with nutrient digestion and absorption (Hassan et al, 2005). Ekpenyong (1985), reports that the poor shelf life of Treculia africana limits its use in the diet, regardless of its known carbohydrate and lipid content.

The seeds of Treculia africana are eaten as a delicacy in Nigeria (especially in the South-Eastern parts of the country). As a result of its poor shelf life, most of the harvested seeds are eaten fresh. If a higher utilization of African bread-fruit, especially in this period of a shortage in food supply, is to be achieved, then preservation techniques must be employed.

This study aims at assessing the effects of the various traditional methods employed in the processing of Treculia africana with a view to identifying which method(s) preserve the nutrients and beneficial phytochemicals, while reducing the anti-nutrient factors. 


\section{MATERIALS AND METHODS}

Procurement and processing of seeds: Five fruit heads of $T$. africana were purchased from the Umuahia central market, Umuahia, Abia state. They were allowed to decompose for 14 days to enable easy manual extraction of the seeds. The extracted seeds were washed thoroughly to remove all traces of the slimy matrix in which the seeds are embedded. The washed seeds were then sorted manually to remove bad seeds and other extraneous materials.

The raw seeds of $T$. africana were divided into 4 equal parts and each part processed by one of the following methods: de-hulling and drying (raw), dehulling and boiling, de-hulling and roasting, and roasting without de-hulling. De-hulling off seeds was done manually. Boiling and roasting of seeds were done in tap water and fine sand respectively. Drying of seeds (to a constant weight) was done in a laboratory oven (Gallenkamp $1 \mathrm{H}-100$ ) at $50^{\circ} \mathrm{C}$. The processed seeds were each ground into fine powder using a laboratory mill and fractions of each were used for the analysis of their constituents.

Proximate analysis of processed seeds: Total ash content was determined by the furnace incineration method as described by James (1995). Crude protein content was determined using the Microkjedahl method (AOAC, 1990). Fat and crude fibre contents were determined the methods described by Pearson (1976). Carbohydrate content was estimated by difference.

Phytochemical analysis of processed seeds: Tannins were estimated using the Folin-Denis spectrophotometric method (Pearson 1976). Flavonoids, alkaloids, oxalates and saponins were determined by the ethyl acetate extraction and gravimetric measurement, the alkaline precipitation and gravimetric method, the oxalate precipitation using potassium permanganate and the double extraction and gravimetric measurement, respectively, as described by Harbone (1973).

Determination of minerals and vitamin A: Calcium and magnesium were determined by the methods described by James (1995). Iron, selenium, copper, iodine and chromium were determined by atomic absorption spectrophotometry as described also by James (1995). Vitamin A concentration was determined by the spectrophotometric method described by Pearson (1976).

Statistical analysis: Data generated from the study were analysed and the descriptive statistics presented as mean \pm standard deviation of three determinations. Differences between means were separated using the ANOVA and multiple comparison tests, with the least significant difference fixed at 0.05 . Analyses were done using the statistical software package SPSS for windows version 11.0 (SPSS Inc. Chicago IL).

\section{RESULTS AND DISCUSSIONS}

Nutrient analyses of processed bread fruit samples indicate that the seeds of $T$. africana are rich in proteins and carbohydrates (Table 1). The protein contents obtained in this study compares well with that obtained by Ekpenyong (1985). The significant decrease in protein content of boiled and dehulled, roasted and undehulled, and roasted and dehulled samples could be attributed to denaturation of the endogenous proteins in the seeds during processing. The higher percentage loss of proteins in undehulled roasted samples could be attributed to losses arising from the interaction of the proteins with anti-nutrients contained in the shell. Dehulling samples before further processing was found to increase the carbohydrate contents of $T$. africana seeds. This could be indicative of the action of endogenous enzymes which may act to release bound carbohydrates from their complexes with nonnutritive components of the seeds (Ugwu and Oranye, 2006). The carbohydrate contents of raw samples compares well with those reported by Renato et al (1998). The lowering of fat content in the processed T. africana seeds could be attributed to losses during drying and roasting. The crude fibre content obtained in this study compares well with those reported by Lawal (1986). Processing resulted in a significant decrease in crude fibre content of dehulled and boiled, and dehulled and roasted samples. Conversely, it resulted in a significant increase in crude fibre content of undehulled roasted samples. This indicates that roasting of $T$. africana preserves the crude fibre content. This would be beneficial against colon cancers and also be useful in aiding bowel movement. Processing resulted in significant decrease in the alkaloids content of the seeds of $T$. africana (Table 2). This could be attributed to leaching of the alkaloids during boiling and also their destruction during roasting. This decrease may be desirable or undesirable as alkaloids are known to impart a bitter taste to most foods. Some alkaloids could be toxic to man and farm animals at high doses. Some alkaloids however are of pharmacological importance and could be beneficial to consumers. Therefore, the reduction in the concentration of such alkaloids during processing could be disadvantageous to consumers of T. africana. Processing also resulted in a significant decrease in phenolic content of all dehulled samples while roasting of the seeds increased their phenolic content. This is not unexpected as the shell is known to have a much higher phenolic content. The tannin content of processed seeds decreased significantly, relative to the raw samples. 
Effect of Traditional Processing Techniques.....

Table 1: Nutrient composition of the seeds subjected to different processing methods

\begin{tabular}{llllc}
\hline & \multicolumn{1}{c}{ Raw } & Boiled-Dried & Roasted-Undehulled & Roasted-Dehulled \\
\hline Ash (\%) & $1.62 \pm 0.02$ & $* 1.27 \pm 0.01$ & $* 3.21 \pm 0.03$ & $* 1.36 \pm 0.02$ \\
Crude Protein $(\%)$ & $18.32 \pm 0.54$ & $* 14.12 \pm 0.20$ & $* 10.62 \pm 0.40$ & $* 13.88 \pm 0.20$ \\
Fat (\%) & $1.31 \pm 0.02$ & $* 1.03 \pm 0.01$ & $* 0.84 \pm 0.02$ & $* 1.23 \pm 0.12$ \\
Crude Fibre (\%) & $1.31 \pm 0.12$ & $* 1.17 \pm 0.01$ & $* 19.11 \pm 0.47$ & $* 1.13 \pm 0.01$ \\
Moisture (\%) & $11.25 \pm 0.15$ & $10.91 \pm 0.03$ & $9.02 \pm 0.05$ & $8.88 \pm 0.05$ \\
Carbohydrate $(\%)$ & $77.44 \pm 8.46$ & $* 82.41 \pm 6.48$ & $* 8.88 \pm 0.05$ & $* 82.40 \pm 6.32$ \\
\hline
\end{tabular}

* indicates mean values that are significantly different from the respective "Raw" portion

Tannins are water soluble polyphenolic compounds located mainly in the seed coat (Kumar et al, 1979; Singh, 1988). The reduction may be due to leaching and or the effect of heat on heat labile tannins contained in $T$. africana seeds. The tannin contents reported in this study compares well with the range reported by Ugwu and Oranye (2006). Flavonoid contents of the samples were significantly decreased by the processing methods employed in this study. This reduction in tannin and flavonoids could be disadvantageous to consumers as the phytochemicals are known to confer some protective effects against some chronic ailments. Flavonoids are known to act as biological antioxidants and their increased consumption is known to protect consumers against some forms of cancers and cardiac diseases. The significant reduction in oxalate and saponnin contents following processing is desirable as saponins as well as oxalates and tannins, at high levels, are known to interfere with digestive processes.

Table 2: Phytochemical contents of the seeds subjected to different processing methods

\begin{tabular}{lcccc}
\hline & Raw & Boiled-Dried & Roasted-Undehulled & Roasted-Dehulled \\
\hline Alkaloid (\%) & $0.58 \pm 0.08$ & $* 0.35 \pm 0.05$ & $* 0.37 \pm 0.03$ & $0.50 \pm 0.05$ \\
Phenols (\%) & $0.82 \pm 0.00$ & $* 0.52 \pm 0.01$ & $* 0.89 \pm 0.00$ & $* 0.45 \pm 0.02$ \\
Tannins (\%) & $0.14 \pm 0.00$ & $* 0.05 \pm 0.00$ & $* 0.06 \pm 0.00$ & $* 0.06 \pm 0.01$ \\
Flavonoid (\%) & $1.30 \pm 0.10$ & $* 0.55 \pm 0.05$ & $* 0.80 \pm 0.10$ & $* 2.15 \pm 0.05$ \\
Oxalate (\%) & $11.37 \pm 0.10$ & $* 8.01 \pm 0.04$ & $* 9.16 \pm 0.06$ & $* 8.43 \pm 0.06$ \\
Saponin (\%) & $0.37 \pm 0.03$ & $* 0.13 \pm 0.03$ & $* 0.17 \pm 0.03$ & $* 0.15 \pm 0.05$ \\
\hline
\end{tabular}

* indicates mean values that are significantly different from the respective "Raw" portion

Table 3: Mineral contents of the seeds subjected to different traditional processing methods

\begin{tabular}{lcccc}
\hline & Raw & Boiled-Dried & Roasted-Undehulled & Roasted-Dehulled \\
\hline Calcium (mg/100g) & $5.34 \pm 1.15$ & $4.68 \pm 1.15$ & $* 7.35 \pm 1.16$ & $3.34 \pm 1.16$ \\
Magnesium (mg/100g) & $2.00 \pm 0.35$ & $1.80 \pm 0.60$ & $* 3.80 \pm 0.35$ & $1.40 \pm 0.35$ \\
Iron $(\mathrm{mg} / 100 \mathrm{~g})$ & $8.00 \pm 0.00$ & $7.00 \pm 0.00$ & $1.10 \pm 0.00$ & $6.00 \pm 0.00$ \\
Selenium $(\mathrm{mg} / 100 \mathrm{~g})$ & $0.18 \pm 2.89$ & $* 0.10 \pm 5.00$ & $* 0.07 \pm 0.03$ & $* 0.07 \pm 0.03$ \\
Copper $(\mathrm{mg} / 100 \mathrm{~g})$ & $0.35 \pm 0.00$ & $0.40 \pm 0.00$ & $0.55 \pm 0.00$ & $0.40 \pm 0.00$ \\
Iodine $(\mathrm{mg} / 100 \mathrm{~g})$ & $0.30 \pm 0.02$ & $* 0.14 \pm 0.03$ & $* 9.31 \pm 0.01$ & $0.23 \pm 0.13$ \\
Chromium $(\mathrm{mg} / 100 \mathrm{~g})$ & $0.04 \pm 0.00$ & $0.04 \pm 0.00$ & $0.06 \pm 0.00$ & $0.02 \pm 0.00$
\end{tabular}

* indicates mean values that are significantly different from the respective "Raw" portion

Boiling and drying significantly reduced the selenium and iodine content of the seeds, relative to the raw samples (Table 3). Roasting of dehulled samples also significantly reduced the selenium content of the seeds. On the other hand, roasting of undehulled seeds increased the calcium, magnesium and iodine contents of the seeds significantly, compared to the raw seeds. Processing did not significantly reduce the quantities of calcium and magnesium in the seeds; reduced significantly the iodine content only in the boiled samples; but significantly reduced the selenium content of the seeds. Many neuromuscular and other cellular functions (like the signaling pathways) require calcium and the recommended calcium allowance for adolescents and adults is 1000$1300 \mathrm{mg} /$ day (FAO/WHO, 2001). Magnesium functions as a co-factor of many enzymes in energy metabolism and biosynthesis of macromolecules, as well as contributes to the maintenance of the electrical potential of nervous tissues and cell membranes (Shils, 1988). The recommended nutrient intake of magnesium is 190-260mg/day for adolescents and adults (FAO/WHO, 2001). The levels of calcium and magnesium found in this study, though not enough to meet the recommended daily intakes, can nonetheless supplement other dietary sources of the minerals. The biological roles of iodine are attributed to the thyroid hormones whose physiological functions are involved in growth and development and control of some metabolic processes in the body (Delange, 1994). As a result, the daily recommended intake of iodine is highest in infants $(30 \mu \mathrm{g} / \mathrm{kg} / \mathrm{day})$ and least in adolescents and adults $(2 \mu \mathrm{g} / \mathrm{kg} / \mathrm{day})$ (FAO/WHO 2001). The low iodine content of the boiled and dried samples may be due to leaching into the water while the higher values got for roasting the dehulled samples may be as a result of roasting liberating the iodine from complexes within the seeds. Much of the selenium in the body is found in proteins as seleno-analogues of sulphur amino acids. Two distinct families of selenium containing enzymes - glutathione peroxidases and thioredoxin reductase - which are involved in protecting against oxidative damage are known (Arthur et al, 1996; Arthur 1997). The recommended nutrient intakes of selenium for adolescents and adults are $20.2-26.2$ 
$\mu \mathrm{g} /$ day (FAO/WHO, 2001). Unfortunately, all forms of processing used in this study reduced the levels of selenium significantly, thereby reducing the quantity available to consumers. For the purposes of selenium supply especially with regards to its anti-oxidant properties, roasting appears to be an unfavourable processing method. The quantities of iodine and selenium found in this study can supplement those got from other sources to meet the recommended daily intakes.

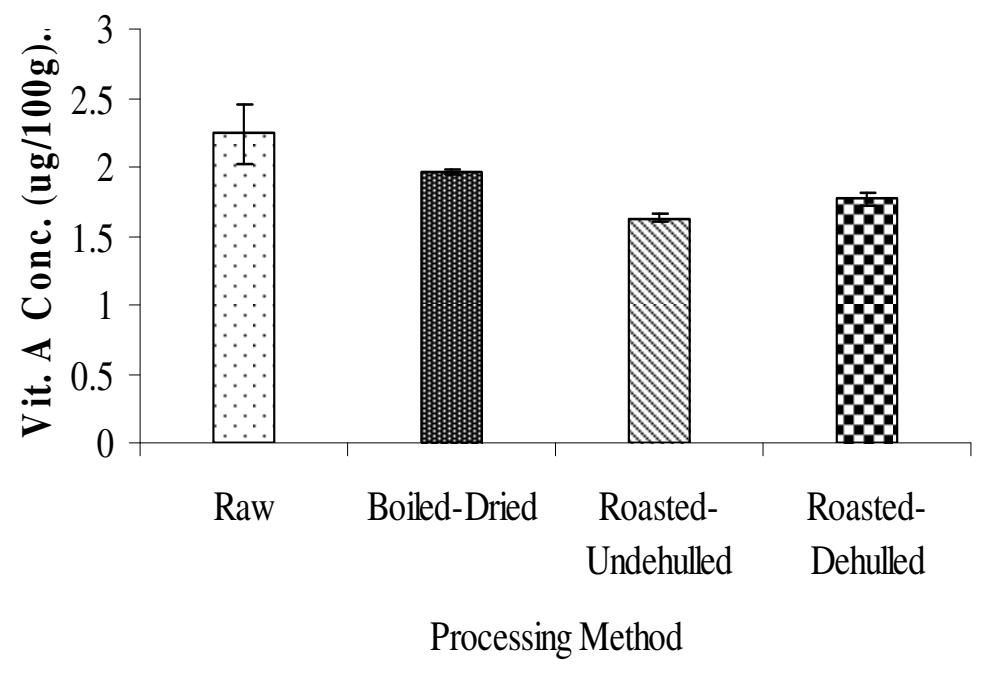

Fig. 1: Levels of vitamin A in the seeds subjected to different traditional processing methods

Finally, our data show that processing reduced significantly the level of vitamin A in the seeds of $T$. africana, with roasting of undehulled samples giving the least value $(1.63 \pm 0.03 \mu \mathrm{g} / 100 \mathrm{~g})$ (Fig. 1). Vitamin A functions at two levels in the body: first and very importantly, in the visual cycle and second to maintain growth and soundness of cells in all body tissues (Blomhoff 1991). Daily requirements of vitamin $\mathrm{A}$ are put at $270-400 \mu \mathrm{g} /$ day while levels up to $600 \mu \mathrm{g} /$ day are considered safe for adolescents and adults (FAO/WHO, 2001). Like selenium, all forms of processing used (especially roasting) appear to be unfavourable methods with respect to vitamin A content of the seeds of $T$. africana.

In conclusion, our data show that boiling and drying the seeds of $T$. africana resulted in less percentage decrease in nutrient and vitamin A composition but higher percentage loss in most phytochemicals. Roasting of undehulled seeds however preserved the mineral elements better than the other processing methods.

\section{REFERENCES}

AOAC (1990). Official Methods of Analysis, Association of Official Analytical Chemists 15 th ed., Washington D.C.

Arthur JR (1997). Selenium biochemistry and function. In: Fischer PWF, L'Abbe MR, Cockell KA, Gibson RS eds. Trace Elements in Man and Animals - 9. proceedings of the $9^{\text {th }}$ Internatonal Symposium on Trace Elements in
Man and Animals. NRC Research Press, Ottawa, Canada pp 1-5.

Arthur JR, Bermano G, Mitchell JH and Hesketh JE (1996). Regulation of selenoprotein gene expression and thyroid hormone metabolism. Biochem Soc Trans 24: 384-8

Blomhoff R (1991). Vitamin A metabolism: new perspectives on absorption, transport, and storage. Physiol Revs 71: 951-90

Delange F (1994). The disorders induced by iodine deficiency. Thyroid 4: 107-28

Ekpenyong TE (1985). Chemical composition and amino acid content of African breadfruit (Treculia africana Decne) Food Chem 17: 59-64

Enujiugha VN and Ayodele-Oni O (2003). Evaluation of nutrients and some anti-nutrients in lesser known underutilized oil-seeds. Int $\mathbf{J}$ Food Sci Tech 38: 525-8

Food and Agricultural Organization (FAO) (1985). The fifth world food survey. FAO, Rome

Food and Agriculture Organization/World Health Organization (2001). Human Vitamin and Mineral Requirements. Report of a joint FAO/WHO expert consultation. Food and Nutrition Division, FAO Rome, pp 161-2 
Effect of Traditional Processing Techniques.....

Giami SY and Wachuku OC. (1997). Composition and functional properties of unprocessed and locally processed seeds from three underutilized food sources in Nigeria. Plant Foods Hum Nutr 50: $27-36$

Harbone JB (1973). Phytochemical Methods: A Guide to Modern Techniques of Plant Analysis. Chapman and Hill, London

Hassan AB, Osman GA and Babiker EE (2005). Effect of domestic processing on antinutrients and availability of protein and mineral of lupin (Lupinus termis) seeds. J Food Technol 3: 2638

James CS (1995). Analytical Chemistry of Food. Chapman Hall, New York

Kumar, NR, Reddy AN and Rao KN (1978). Levels of phenolic substances in the leachates in Cicer seed. Ind J Experiment Biol 17: 114-6
Latham MC (1997). Human Nutrition in the Developing World. Food and Nutrition Series No 29, Food and Agriculture Organization of the United Nations, (FAO) Rome.

Lawal RO (1986). Effect of roasting on the chemical composition of Treculia africana. Food Chem 22: $305-7$

Pearson D (1976). The Chemical Analysis of Foods. $7^{\text {th }}$ ed., Churchill Livingstone, Edingburg

Shils ME (1988). Magnesium in health and disease. Annu Rev Nutr 8: 429-60

Singh U (1988). Antinutritional factors of chick pea and pigeon pea and their removal by processing. Plant Foods Hum Nutr 38: 251-61

Ugwu FM and Oranye NA (2006). Effect of some processing methods on the toxic components of African bread fruit (Treculia africana). J Biotech 5: 2329-33 